\title{
Effect of Mergers and Acquisitions on Market Concentration and Interest Spread
}

\author{
${ }^{*}$ Mehwish Aziz Khan ${ }^{1}$, Ferheen Kayani², Attiya Javid ${ }^{3}$ \\ ${ }^{1}$ Federal Urdu University of Arts, Science \& Technology, Islamabad, Pakistan \\ ${ }^{2}$ COMSATS Institute of Information Technology, Islamabad, Pakistan \\ 3PIDE, Quaid-i-Azam University Campus, Islamabad, Pakistan \\ *mehwishazizkhan@gmail.com
}

\begin{abstract}
This study investigates the relationship of mergers \& acquisitions with the interest spread of the banking industry in Pakistan. To assess whether the merger of Pakistani banks were a success or otherwise, profitability, liquidity ratios, and net interest spread are computed which are considered essential to judge the financial performance of any bank. Data is taken for the period of 1997-2010 and this data have been used to calculate the interest spread and market concentration. Market Concentration is calculated by using Herfindahl-Hirschman Index or HHI. Findings show that the profitability and net interest spread of two merged banks declines as a result of mergers. It is also revealed that Concentration of the banking industry shows a rising trend during 2008 and 2009 after mergers occurred during 2007 as a result of merger. However, it shows the level that almost approaches the threshold i.e. 1000. One or two more mergers can push up threshold level of HH index. It means that it is the right time for banking industry of Pakistan to be reviewed by any antitrust authority to maintain the optimum level of competition.
\end{abstract}

Keywords: Mergers \& Acquisitions, Market Concentration, Banking industry, Interest Spread, and Profitability.

\section{Introduction}

Difference between banks' earning on assets and interest paid on deposits is termed as interest spread, which has been on a growing trend in the last few years. There are so many factors, which influences the net interest spread. The particular characteristics of commercial banks that are typically considered to have an effect on their spreads include the size of the bank, ownership pattern, the quality of the loan portfolio, capital sufficiency, overhead costs, operating expenses, market share and shares of current and fixed assets (Demirguc-Kunt , 1998; Moore \& Craigwell, 2000 \& Sologoub, 2006). Hannan \& Liang (1993) \& Bajaras, Steiner, \& Salazar (1999) provide hint that spread may go higher due to industry concentration. Market concentration is number of firms and their respective shares in a market. When one business takes over another and evidently recognized itself as the new owner, the purchase is called an acquisition. A merger takes place when two firms, frequently of about the same size, agree to go ahead as a single new company rather than independently owned and operated. Mergers and Acquisitions (abbreviated M\&A) refers to the aspect of corporate strategy, finance and management dealing with the buying, selling and combining of different companies that can aid, finance, or help a growing company in a given industry grow rapidly without having to create another business entity.

During the past few years, banking sector mergers and acquisition are showing increasing trend. This is because of State Bank of Pakistan's (abbreviated SBP) instructions to Commercial banks whereby they are required to increase their capital to RS. 6 Billion by December 2009 in compliance with Basel II requirements. Some of the banks in local industry find it difficult to meet the capital requirement by given deadline. Equity injection and/or reinvestment of profits are not enough to cover the gap between their existing capital and required slab of Rs. 6 Billion. This scenario leads them seeking opportunity of merger or acquisition to increase their capital to the required level. The current situation of Merger and acquisition will leave the customers/savers with limited choices and this would finally result in rising spreads for the banks. Typically, industry concentration is increased through the effect of M\&A on competition. Market power increases with rise in market share that enable the banks to control and increase spreads, which affect negatively its customers (Simons \& Stavins, 1998). Merging banks can get scale economies through Mergers \& Acquisitions thus improving efficiency, however, they lessen the competition that increases market power to charge higher interest spread, so any further decrease in competition due to this activity possibly will call for review from antitrust perspective. 
In many countries, proposals for mergers and acquisition are reviewed to check its impacts on the industry. The mergers and acquisition may be restricted if the same is threatening to the competition in local market as some times M\&A results in falling the degree of competition below to a certain specified level by the country. Certain rules are defined to deal with M\&A and bodies are assigned the task to review and approve M\&A e.g. Fed. Along with some other organization, in U.S approves the mergers and acquisition. Furthermore, a review on competitive aspects of all proposed bank merger is provided by the antitrust division of the department of justice and is authorized to sue merger proposal that will have significant adverse effect on competition. The US department of justice has defined three threshold levels for HHI to find out the market structure in an industry. These are: (i) A HHI index below 0.1 (or 1,000) show an unconcentrated index. (ii) A HHI index between 0.1 to 0.18 (or 1,000 to 1,800 ) indicates moderate concentration. (iii) A HHI index above 0.18 (above 1,800) indicates high concentration.

According to Austin (2002) banking regulators are more inclined towards concentration in order to maintain and run a smooth banking industry. Contrary to that public wants more competition in the market so that they may get increased returns on their savings and investments. Due to this very factor, central banks are although suitable choice to review M\&A proposals from the perspective of financial soundness of banks and overall industry, yet they are not suitable to review the proposal from antitrust perspective. The conclusion is Central bank should review the proposals of M\&A to grant approval but at the same time; these proposals must also be reviewed by a competent antitrust authority having the powers to decline M\&A having significant negative impacts on competition in the market. In case of Pakistan, approval for Mergers of banks falls under the purview of SBP along with Securities \& Exchange Commission of Pakistan (abbreviated SECP). The criteria used for the purpose is not easily available, not even a proper system to consider public opinion or complaints of the stakeholders, particularly those of depositors. This study investigates the relationship of M\&A and interest spread of the banking industry in Pakistan, and explores whether concentration ratio of banking sector of Pakistan after M\&A is approaching the limit or not where there is a need for bringing banking mergers and acquisitions under the jurisdiction of antitrust authority.

\section{Literature Review}

Literature has explored various determinants of interest spread including three main categories which are Firm Variables (e.g. Market share, Liquidity, Administrative cost, Non-performing loans), Industry Variables (e.g. Concentration), and Macro Variables (e.g. Inflation). Bawumi et al (2005) concluded that the market share variable is very dominating in explaining spreads. High operating cost, the existence of liquidity reserves, and non-performing loans, also contribute to the wide spreads. The particular characteristics of commercial banks that are typically considered to have an effect on their spreads include the size of the bank, ownership pattern, the quality of the loan portfolio, capital sufficiency, overhead costs, operating expenses, and shares of current and fixed assets (Demirguc-Kunt, 1998; Moore \& Craigwell, 2000 \& Sologoub, 2006). Kahn et al. (2000) showed that mergers lead to greater market power in the pricing of personal loans. Esty et al. (1996) found that the level of acquisition activity is more positively associated with yield curve spreads for banks than for non-banks. Bank mergers make markets more concentrated and elevates market power as a result banks pay lower deposit interest rates which increases spread (Simons \& Stavins, 1998). Hannan and Liang (1993) and Bajaras, Steiner, and Salazar (1999) among others, suggested that industry concentration may lead to higher spread. Market concentration has a positive and significant effect on the level of personal loan (Kahn, et al. 2000). Herfindhal index is a traditional measure of market concentration, which cannot describe the life cycle of the interest rate gain (Kim, et al. 2006).

Prager and Hannan (1998) studied the significant effect of bank mergers on market concentration. He found that merging banks are not passing on efficiency profits to their customers but, instead, are exercising monopoly power. Sapienza (1998) investigated the effect of mergers on business lending. She found that greater are the market shares of the merging banks, the less interest rates tend to fall, and for sufficiently high market shares, mergers lead to loan rate increases. Hence, these results proposed that when mergers bring significant increases in concentration, banks exercise market power.

Concentration will increase market power thus prevent competition and efficiency. Bank mergers and acquisitions increased concentration that increases banks profitability by increasing net spread margins (Demirguc-Kunt \& Levine, 2000). Typically, industry concentration is increased through the effect of M\&as on competition. Bank concentration has a positive effect on financial distress (Cipollin \& Fiordelisi 
2009). Mergers and acquisitions have double effect. One, it allows merging banks to improve efficiency by having large-scale economies and secondly it results in lesser competition in the market which increase market power of the banks in industry. As a result, banks are enabled to increase interest spreads. Bank concentration is not robustly linked with process of financial sector development and competency (Demirguc-Kunt, 2000). Austin (2002) revealed that regulator's interest in maintaining the stability of the banking system leans towards greater concentration whereas public's intention of maximizing its return calls for a competitive banking industry. Antitrust policy in banking is important for the nation's economic health. It has to be set on firmer experiential ground (Simons \& Stavins, 1998).

According to previous researches, there are so many factors that influence interest spread including size of the bank, the quality of the loan portfolio, non performing loans, capital sufficiency, overhead costs, operating expenses, market share and liquidity (Demirguc-Kunt, 1998; Moore \& Craigwell, 2000 \& Sologoub, 2006). Market share variable is very dominating in explaining spreads (Bawumi et al, 2005). Hannan and Liang (1993) and Bajaras, Steiner, and Salazar (1999) among others, suggested that industry concentration may lead to higher spread. The variable of primary interest is bank interest spread and the two independent variables are Market concentration and Mergers \& acquisitions.

The increased activity of Mergers \& Acquisitions in any industry reduces the no. of firms as a result market concentration increases. Sapienza (1998) found that when mergers bring significant increase in concentration, banks exercise market power. Concentration will increase market power thus prevent competition and efficiency (Demirguc-Kunt, 2000). This will lead to our first research hypothesis that:

$H_{1}$ : Bank Mergers raise market concentration: When two banks merge to work more efficiently, they should bring economies of scale and give benefits to its customers. In actual when market power increases because of high market share and concentration, banks elevate the spread to the harm of its customers by charging more on loans or paying less to depositors or some mixture of the two. Prager and Hannan (1998) found that merging banks are not passing on efficiency profits to their customers but, instead, are exercising monopoly power. Greater are the market shares of the merging banks, the less interest rates tend to fall, and for sufficiently high market shares, mergers lead to loan rate increases (Sapienza,1998; Simons, 1998), this will lead to our next hypothesis:

\section{$\mathrm{H}_{2}:$ Market concentration raises interest spread.}

\section{Methodology}

Pakistan's banking industry primarily comprise of seven different groups: (i) Four Public Sector Banks (ii) Four speacialized banks (iii) Twenty Private banks (iv) Five Islamic banks (v) Seven Foreign banks (vi) Seven Micro Finance banks and (vii) Eight DFI. The sample of current study is only those banks which have been mergerd or acqired after 2002 for the calculations of interest spread and profitability \& liquidity ratios (Tarawneh, 2006). To accomplish the aforementioned research objectives, the data for this study was gathered from the"Banking Statistics of Pakistan" published annually for the period of 1997-2010 of 28 banks and this data have been used to calculate the market concentration.

Interest Spread: Interest Spread is measured as the difference between the average interest rate earned on loans and paid on deposits (Tennant, 2007). It was calculated as:

Interest Spread $=$ Return on average assets - cost of average funds

Return on average assets $=$ Total interest income earned over average assets

Average assets $=$ Average loans and advances + Liquid, interest earning investments

Average cost of funds = Total interest paid by the bank over all borrowed funds i.e. Deposits plus Borrowings (Khawaja and Musleh, 2007)

Market Concentration: Market Concentration is calculated by using Herfindahl-Hirschman Index or HHI (Khawaja and Musleh, 2007). It is a measure of the size of firms in relation to the industry and an indicator of the amount of competition among them. The formula for $\mathrm{HHI}$ is:

$H=\sum_{i=1}^{N} S_{i}^{2}$

Where $s_{i}$ is the market share of firm $i$ in the market and $N$ is the number of firms. 
Data Analysis: The results of the above mentioned variable i.e. Market Concentration before and after the M\&A are analyzed, through criteria of merger guidelines published by antitrust division of United States which is as follows:

(i) $\quad \mathrm{A} \mathrm{HHI}$ index below 0.1 (or 1,000) indicates an unconcentrated index.

(ii) $\quad \mathrm{A} \mathrm{HHI}$ index between 0.1 to 0.18 (or 1,000 to 1,800 ) indicates moderate concentration.

(iii) A HHI index above 0.18 (above 1,800) indicates high concentration.

\section{Results}

Merger - PICIC Commercial Bank and NIB Bank: NIB Bank acquired PICIC Commercial Bank in January, 2008. To assess whether the merger of PICIC Commercial Bank and NIB Bank was a success or otherwise, profitability, liquidity ratios, and net interest spread are computed which are considered essential to judge the financial performance of any bank (Tarawneh, 2006).. The table 1 shows the ratios leading to assessment of financial performance in terms of profitability and liquidity before merger. These ratios have been averaged in the last column.

Table 1: Key Ratios of PICIC Commercial Bank and NIB Bank (Pre-merger Periods)

\begin{tabular}{llllll}
\hline \multirow{2}{*}{ Ratios } & \multicolumn{2}{c}{ Pre-Merger } & \multicolumn{2}{c}{ Pre-Merger } & \multirow{2}{*}{ Pre-Merger } \\
\cline { 2 - 5 } & \multicolumn{2}{c}{ PICIC Comm. Bank } & \multicolumn{2}{c}{ NIB Bank } & \multirow{2}{*}{ Average } \\
\cline { 2 - 5 } & $\mathbf{2 0 0 6}$ & $\mathbf{2 0 0 5}$ & $\mathbf{2 0 0 6}$ & $\mathbf{2 0 0 5}$ & \\
\hline Net Interest Spread & $39.10 \%$ & $50.58 \%$ & $29.92 \%$ & $34.83 \%$ & $38.61 \%$ \\
Markup Earned to Total Assets & $8.25 \%$ & $6.41 \%$ & $7.54 \%$ & $5.36 \%$ & $6.89 \%$ \\
Net Markup Income to Total Assets & $3.22 \%$ & $3.24 \%$ & $2.26 \%$ & $1.87 \%$ & $2.65 \%$ \\
Non-Markup Income to Total Assets & $1.22 \%$ & $1.47 \%$ & $0.02 \%$ & $-0.01 \%$ & $0.67 \%$ \\
Profit Before Taxation to Total Assets & $1.82 \%$ & $2.93 \%$ & $0.06 \%$ & $0.08 \%$ & $1.22 \%$ \\
Profit After Taxation to Total Assets & $1.38 \%$ & $2.31 \%$ & $0.21 \%$ & $0.24 \%$ & $1.03 \%$ \\
Profit After Tax to Total Equity & $21.67 \%$ & $35.93 \%$ & $2.19 \%$ & $1.82 \%$ & $15.40 \%$ \\
Deposits to Total Asset & $84.60 \%$ & $82.10 \%$ & $65.84 \%$ & $65.97 \%$ & $74.63 \%$ \\
Total Equity to Total Assets & $6.36 \%$ & $6.43 \%$ & $9.43 \%$ & $13.22 \%$ & $8.86 \%$ \\
Total Liabilities to Total Assets & $94.20 \%$ & $93.77 \%$ & $90.67 \%$ & $86.84 \%$ & $91.37 \%$ \\
\hline
\end{tabular}

Table 2: Ratios of NIB Bank for post-merger periods (Last column gives two years' average)

\section{Ratios}

NIB Bank (Post Merger)

\begin{tabular}{llll}
\hline Net Interest Spread & $30.11 \%$ & $29.47 \%$ & $29.79 \%$ \\
Markup Earned to Total Assets & $8.84 \%$ & $8.93 \%$ & $8.88 \%$ \\
Net Markup Income to Total Assets & $2.66 \%$ & $2.63 \%$ & $2.65 \%$ \\
Non-Markup Income to Total Assets & $-0.17 \%$ & $-3.93 \%$ & $-2.05 \%$ \\
Profit Before Taxation to Total Assets & $0.75 \%$ & $-7.62 \%$ & $-3.44 \%$ \\
Profit After Taxation to Total Assets & $0.72 \%$ & $-5.38 \%$ & $-2.33 \%$ \\
Profit After Tax to Total Equity & $3.57 \%$ & $22.73 \%$ & $-9.58 \%$ \\
Deposits to Total Asset & $44.87 \%$ & $60.81 \%$ & $52.84 \%$ \\
Total Equity to Total Assets & $20.21 \%$ & $23.66 \%$ & 21.94 \\
Total Liabilities to Total Assets & $80.01 \%$ & $81.09 \%$ & $80.55 \%$ \\
\hline
\end{tabular}

In the table 3, averages of these ratios for pre-and post-merger periods have been analyzed. Out of 10 ratios, there was improvement in 3 ratios with deterioration in 6 ratios as a result of merger. Only one ratio (i.e. Net Markup Income to Total Assets) is equaled for pre- and post merger periods. Thus, it is concluded that this merger has proved to be a failure during post as at December 31, 2009. This result is not in consistent with the findings of the study conducted by Demirguc-Kunt, 2000. 
Table 3: Average Key Ratios (Pre- and Post-merger Periods)

\begin{tabular}{llll}
\hline Ratios & $\begin{array}{c}\text { Pre-Merger } \\
\text { Average Ratios }\end{array}$ & $\begin{array}{c}\text { Post-Merger } \\
\text { Average Ratios }\end{array}$ & Analysis \\
\hline Net Interest Spread & $38.61 \%$ & $29.79 \%$ & Deteriorated \\
Markup Earned to Total Assets & $6.89 \%$ & $8.88 \%$ & Improved \\
Net Markup Income to Total Assets & $2.65 \%$ & $2.65 \%$ & No change \\
Non-Markup Income to Total Assets & $0.67 \%$ & $-2.05 \%$ & Deteriorated \\
Profit Before Taxation to Total Assets & $1.22 \%$ & $-3.44 \%$ & Deteriorated \\
Profit After Taxation to Total Assets & $1.03 \%$ & $-2.33 \%$ & Deteriorated \\
Profit After Tax to Total Equity & $15.40 \%$ & $-9.58 \%$ & Deteriorated \\
Deposits to Total Asset & $74.63 \%$ & $52.84 \%$ & Deteriorated \\
Total Equity to Total Assets & $8.86 \%$ & 21.94 & Improved \\
Total Liabilities to Total Assets & $91.37 \%$ & $80.55 \%$ & Improved \\
\hline
\end{tabular}

Merger - Standard Chartered Bank and Union Bank Limited: Union Bank Limited merged with Standard Chartered Bank on 29th December 2006. The table 4 shows the ratios leading to assessment of financial performance in terms of profitability and liquidity before merger. These ratios have been averaged in last column of the table.

Table 4: Pre Mergers Ratio of Standard Chartered Bank

\begin{tabular}{llll}
\hline Ratios & $\mathbf{2 0 0 6}$ & $\mathbf{2 0 0 5}$ & Average \\
\hline Net Interest Spread & $70.33 \%$ & $74.62 \%$ & $72.48 \%$ \\
Markup Earned to Total Assets & $5.95 \%$ & $6.35 \%$ & $6.15 \%$ \\
Net Markup Income to Total Assets & $4.18 \%$ & $4.73 \%$ & $4.46 \%$ \\
Non-Markup Income to Total Assets & $1.47 \%$ & $2.15 \%$ & $1.81 \%$ \\
Profit Before Taxation to Total Assets & $2.87 \%$ & $4.84 \%$ & $3.86 \%$ \\
Profit After Taxation to Total Assets & $2.23 \%$ & $3.63 \%$ & $2.93 \%$ \\
Profit After Tax to Total Equity & $13.57 \%$ & $45.04 \%$ & $29.31 \%$ \\
Deposits to Total Asset & $62.68 \%$ & $73.60 \%$ & $68.14 \%$ \\
Total Equity to Total Assets & $16.41 \%$ & $8.06 \%$ & $12.24 \%$ \\
Total Liabilities to Total Assets & $83.59 \%$ & $91.93 \%$ & $87.76 \%$ \\
\hline
\end{tabular}

The table 5 shows the results of Ratios for three years after merger. These ratios have been averaged in last column of the table.

Table 5: Post Mergers Ratio of Standard Chartered Bank

\begin{tabular}{lllll}
\hline Ratios & $\mathbf{2 0 0 9}$ & $\mathbf{2 0 0 8}$ & $\mathbf{2 0 0 7}$ & Average \\
\hline Net Interest Spread & $61.09 \%$ & $70.45 \%$ & $71.87 \%$ & $67.80 \%$ \\
Markup Earned to Total Assets & $8.52 \%$ & $8.80 \%$ & $8.82 \%$ & $8.71 \%$ \\
Net Markup Income to Total Assets & $5.20 \%$ & $6.20 \%$ & $6.34 \%$ & $5.91 \%$ \\
Non-Markup Income to Total Assets & $2.20 \%$ & $2.49 \%$ & $2.39 \%$ & $2.36 \%$ \\
Profit Before Taxation to Total Assets & $0.40 \%$ & $0.41 \%$ & $1.60 \%$ & $0.80 \%$ \\
Profit After Taxation to Total Assets & $0.21 \%$ & $0.23 \%$ & $1.08 \%$ & $0.51 \%$ \\
Profit After Tax to Total Equity & $1.40 \%$ & $1.47 \%$ & $6.42 \%$ & $3.10 \%$ \\
Deposits to Total Asset & $66.14 \%$ & $65.96 \%$ & $69.33 \%$ & $67.14 \%$ \\
Total Equity to Total Assets & $15.26 \%$ & $16.15 \%$ & $16.85 \%$ & $16.09 \%$ \\
Total Liabilities to Total Assets & $84.73 \%$ & $83.84 \%$ & $83.15 \%$ & $83.91 \%$ \\
\hline
\end{tabular}

In the table 6 , averages of these ratios for pre-and post-merger periods have been analyzed. Out of 10 ratios, there was improvement in 4 ratios with deterioration in 6 ratios as a result of merger. 
Table 6: Average Key Ratios (Pre- and Post-merger Periods)

\begin{tabular}{llll}
\hline Ratios & $\begin{array}{c}\text { Pre-Merger } \\
\text { Average Ratios }\end{array}$ & $\begin{array}{c}\text { Post-Merger } \\
\text { Average Ratios }\end{array}$ & Analysis \\
\hline Net Interest Spread & $72.48 \%$ & $67.80 \%$ & Deteriorated \\
Markup Earned to Total Assets & $6.15 \%$ & $8.71 \%$ & Improved \\
Net Markup Income to Total Assets & $4.46 \%$ & $5.91 \%$ & Improved \\
Non-Markup Income to Total Assets & $1.81 \%$ & $2.36 \%$ & Improved \\
Profit Before Taxation to Total Assets & $3.86 \%$ & $0.80 \%$ & Deteriorated \\
Profit After Taxation to Total Assets & $2.93 \%$ & $0.51 \%$ & Deteriorated \\
Profit After Tax to Total Equity & $29.31 \%$ & $3.10 \%$ & Deteriorated \\
Deposits to Total Asset & $68.14 \%$ & $67.14 \%$ & Deteriorated \\
Total Equity to Total Assets & $12.24 \%$ & $16.09 \%$ & Deteriorated \\
Total Liabilities to Total Assets & $87.76 \%$ & $83.91 \%$ & Improved \\
\hline
\end{tabular}

Thus, the results are not showing the successful outcomes of merger till December 31, 2009. Net interest spread of both the banks is reducing after the merger. These results are not supporting the previous studies conducted by Esty, 1996; Simons \& Stavins, 1998; Sapienza, 1998; and Demirguc-Kunt, 2000 that states that the level of acquisition activity is more positively associated with yield curve spreads for banks than for non-banks. However, this can be cover up by the argument that banks and their management will take time to adjust. Two years are not enough to judge their performance.

Banking Industry Concentration: The trend of concentration of banking industry based on Herfindhal index is shown in the table 7.

Table 7: Banking Industry Concentration

\begin{tabular}{ll}
\hline Year & Concentration Ratio (HHI) \\
\hline 1997 & 1585 \\
1998 & 1598 \\
1999 & 1492 \\
2000 & 1488 \\
2001 & 1185 \\
2002 & 1130 \\
2003 & 1032 \\
2004 & 946 \\
2005 & 833 \\
2006 & 810 \\
2007 & 785 \\
2008 & 922 \\
2009 & 918 \\
\hline
\end{tabular}

The industry is showing a declining trend over the years. During 1997 to 2002, industry concentration is very high ranging from 1100 to 1600 . It shows that in this time period industry is almost moderately concentrated and captured by large players and very few numbers of small banks. After 2003, concentration ratio shows declining trend because there were new private banks start introducing in the banking industry. These results are consistent with the findings of the study conducted by Khawaja and Musleh (2007). This can be due to the privatization, deregulation, and liberalization in financial markets of Pakistan. In 2007; two huge mergers of the banking industry have taken place. Results reveal that industry again shows rising trend to some extent by 2009 that is almost near to the threshold level. A merger or two can push the concentration above the threshold level of 1000.

\section{Discussion and Conclusion}

This study assessed the relationship of M\&A and industry concentration with the interest spread. Findings disclosed that the industry concentration shows a rising trend as a result of merger. The first hypothesis of this study has been accepted and supported by the argument of Sapienza (1998). He emphasized that mergers bring significant increase in concentration of the banking industry. However, 
concentration ratio shows the level that almost approaches the threshold level i.e. 1000. One or two more mergers can push up threshold level of HH index. It means that it is the right time for banking industry of Pakistan to be reviewed by any antitrust authority to maintain the optimum level of competition.

Findings show that the profitability and net interest spread of two merged banks declines as a result of mergers. However, they fail to meet financial expectations up till now. They could not show successful management of integrating people and their organizational cultures, which is the key to achieving desired M\&A outcomes. Concentration of the banking industry increases during 2008 and 2009 after mergers occurred during 2007. However, net interest spread of the merged banks shown a declining trend in these years which means that concentration do not lead to high interest spread. The second hypothesis of this study is being rejected. The results of Kim et al (2006) who argued that Herfindhal index is a traditional measure of market concentration, which cannot describe the life cycle of the interest rate gain matched with the results of this study.

Pakistan needs a competition policy in the wake of the merger movement as well as because of privatization, deregulation, and liberalization, which have occurred in its domestic economies. Mostly, regulators interest inclined towards greater market concentration in order to maintain a smooth and stable banking system. However, public want to maximize their return and they call for a high degree of competition which suits their intentions. This difference in approach requires that SBP should not review the proposal from antitrust outlook. Rather, for this purpose an Antitrust Authority/body must be introduced/ organized having sufficient powers to decline any merger proposal that they think will post considerable negative impacts on competition in Pakistan banking industry.

Acknowledgement: We wish to express our appreciation to Dr. Attiya Javid for introducing new dimensions of knowledge to us, where we have explored our mental abilities and widened our horizon of knowledge.

\section{References}

Austin, J. V. (2002). The role of supervisory authorities in connection with bank mergers. <johnvaustin@comcast.net>.

Barajas, A., Steiner, R. \& Salazar, N. (1999). Interest rate spreads in banking in Colombia. IMF Staff Papers, $46,196-224$.

Bawumia, M., Belnye, F. \& Ofori, E. M. (2005). The determination of bank interest spreads in Ghana: An empirical analysis of panel data. (WP/BOG-2005/09).

Cipollini, A. \& Fiordelisi, F. (2009). The impact of bank concentration on financial distress: The case of the European banking system. EMFI WPs, 2 - 2009.

Demirguc-Kunt, A. \& Levine, R. (2000). Bank concentration: cross-country evidence. World Bank.

Demirguc-Kunt, A. \& Huizinga, H. (1998). Determinants of commercial bank interest margins and profitability: Some international evidence. World Bank Policy Research Working Papers, WPS1900.

Esty, B., Narasimhan, B. \& Tufano, P. (1996). Interest-rate exposure and bank mergers. Working paper, Department of Finance, Pennsylvania University.

Hannan, T. \& Liang, J. N. (1993). Bank commercial lending and the influence of thrift competition. Finance and Economics Discussion Series 93-39 (Washington, DC: U.S. Board of Governors of the Federal Reserve System).

Kahn, C., Pennacchi, G. \& Sopranzetti, B. (2000). Bank consolidation and consumer loan interest rates. Working Paper, Department of Finance, Pennsylvania University.

Khawaja, I. \& Musleh-ud, D. (2007). Determinants of interest spread in Pakistan. Working Paper Pakistan Institute of Development Economics.

Kim, M., Kristiansen, G. E. \& Vale, B. (2006). What determines banks' market power? Akerlof or Herfindahl. Working Paper from Norges Bank.

Moore, W. \& Craigwell, R. (2000). Market power and interest rate spreads in the Caribbean. Paper presented at the XXXII Annual Monetary Studies Conference, Kingston, Jamaica, 2 November 2000.

Prager, R. A. \& Hannan, H. T. (1998). Do substantial horizontal mergers generate significant price effects? Evidence from the Banking Industry. Journal of Industrial Economics, 46, 433-52.

Sapienza, P. (1998). The effects of bank mergers on loan contracts. Working paper, Department of Finance, Northwestern University. 
Simons, K., and Stavins, J. (1998). Has Antitrust Policy in Banking Become Obsolete? New England Economic Review, March/April 1998, 13-26.

Sologoub, D. (2006). The determinants of bank interest margins and profitability: Case of Ukraine. Workshop on transition economics, Helsinki, April 7-8, 2006.

Tarawneh, M. (2006). A comparison of financial performance in the banking sector: some evidence from Omani commercial banks. International Research Journal of Finance and Economic, (3), 101-112.

Tennant, D. \& Folawewo, A. (2007). Macroeconomic and market determinants of banking sector interest rate spreads: Empirical evidence from low and middle income countries. Retrieved January 1, 2011 from http://www.sbp.org.pk. 